\title{
Investigation of the Effects of the Talent Identification Tests Used by the Coaches in Wrestling on Success
}

\author{
Ömer Kaynar \\ School of Physical Education and Sport, Muş Alparslan University, Turkey
}

Copyright $\mathrm{C} 2019$ by authors, all rights reserved. Authors agree that this article remains permanently open access under the terms of the Creative Commons Attribution License 4.0 International License

\begin{abstract}
Detection of a talented individual in sports and steering $\mathrm{him} / \mathrm{her}$ to the relevant sports branch is very important for sports success. Therefore, this study aims to investigate the effects of the Talent Identification Tests used by the coaches in wrestling on success. In this research, qualitative research technique was used. The participants of the study are 165 voluntary coaches working in youth setups, amateur clubs, professional clubs and the national team and having an average of eight years of coaching experience in 45 provinces of Turkey in seven different geographical regions. In this qualitative research, Semi-structured interview form developed by the researchers was used as a data collection tool. The data were obtained by the expert researchers in the related field and analysed via NVIVO. Of the 165 coaches in the present study, $106(64.24 \%)$ were detected to perform a talent test for the athletes who just started to wrestle and $59(35.76 \%)$ were detected not to apply a talent test. $41(38.68 \%)$ of the coaches who applied talent tests to the wrestlers grounded their assessment on basic motoric characteristics of wrestlers, 36 (33.96\%) physical structures and wrestling tendencies of the athletes, $19(17.92 \%)$ on the competition observations and technical characteristics and $10(9.43 \%)$ on intelligence. In conclusion, it can be asserted that wrestling coaches' talent identification tests applied to athletes are effective in identification the athlete candidates who may be successful.
\end{abstract}

Keywords Wrestling, Wrestling Coaches, Talent Identification Tests, Success

\section{Introduction}

Being talented in sports is one of the ways to be successful. For this reason, many sports clubs, coaches and professional teams use talent tests to identify talented athletes $[1,2]$.

The concept of talent is defined as "a person's ability to understand or do something, capability and aptitude" in
Turkish Language Institution. Although the concept of sportive talent varies by sports branches, it is generally defined as follows: The whole of the genetic factors that are effective in the sporting achievement, innate physical and physiological capacity and features such as mental skills and high performance [3]. Today, many talent identification programs are used to identify successful athletes. The most popular of these programs is undoubtedly talent identification (TID) programs. TID programs are designed to detect young athletes with potential for success in Olympic sports [4]. Talent identification programs have increased in popularity with the development of many test batteries that have been used to identify successful athletes. This program is based on the talent selection criterion, which is generally applied regardless of potential and maturation processes of athletes. As the advantages of anthropometric, aerobic and anaerobic power are dependent on a certain maturation process in athletes, maturation has an important place in talent identification programs [5].

In a study conducted on footballers, it was emphasized that in order to identify the ability in football, not only physiological aspects but also skills, technical, psychological and sociological aspects should be evaluated [6].

Many models have been developed to improve the ability in many studies $[7,8]$. It was stated that the pacing model developed by Elferink-Gems et al. [9] in talent development will contribute to the performances of athletes in endurance sports. In addition, Elferink- Gemser et al. [9] suggest that this model can be used by trainers and coaches for talent development.

When performing skill identification and development programs in the field, coaches should assess the factors that contribute to high-level performance in athletes according to their preadolescence and postpubertal period $[10,11]$.

It is known that there are two methods used in determining the talent selection in sports science; natural selection and scientific selection [12]. Natural selection is defined as an individual's starting a sport which is randomly selected, regardless of whether the individual is 
talented or not, by his family, his coach or his instructor [13]. Scientific selection is defined as talent tests applied by experts to the athlete candidates who are prone to any sports branch and to direct them to the sport they can be efficient [13].

It is observed that talent tests are conducted in many sports branches $[14,15]$. In order to identify the talents of children in the age group of 7-12,30 m sprint and eight run tests were applied in the first stage. In the age group of 11-12, grip strength, $20 \mathrm{sec}$. sit-ups, $30 \mathrm{~m}(20+10 \mathrm{~m})$ speed run, sit-and-reach, eight runs, standing long jump, health ball launch, shuttle run tests were applied in the second stage [16]. In the elite young footballers, physical performance tests such as vertical jump, sprints over 10 and $20 \mathrm{~m}$ and agility test were applied [17].

Furthermore, physical and physiological characteristics, anthropometric structure, somatotype characteristics, and psychological factors are reported to be important parameters in determining the talented athletes $[18,19]$. Genetic, particularly in recent years, tests have started to be used to identify the talent selection criteria in sports as of the realization of the human genome project $[21,22]$.

Wrestling, which is the ancestral sport in Turkey, is a sports branch winning the most medals in international sports events [22]. The international success in this sport can be sustained by the detection of talented athletes and directing them to the relevant sport. In the literature review, no study was found examining the effect of the talent test applications of the coaches on sportive success in the wrestling sport.

Therefore, this study aims to examine the effect of the talent identification tests used by the coaches in the wrestling

\section{Materials and Methods}

This section of the research gives information about the research model, study group, data collection tool, data collection process, and data analysis.

\subsection{Research Model}

Semi-structured interview technique was used in this study, which is conducted based on the qualitative data collection technique. Semi-structured interview form developed by the researchers was used as data collection tool in the study.

\subsection{Study Group}

The study group of the study consist of 165 voluntary coaches working in youth setups, amateur clubs, professional clubs and the national team in 45 provinces of Turkey in seven different geographical regions with the average age of 37 .

\subsection{Data Collection Tool}

The semi-structured interview form, which was preferred in written, was developed to identify the talent test of the coaches. Questions regarding the identification of personal information of the coaches participating in our study such as 'education background of coaches, coaching experience, levels, and categories, are included in the interview form. In order to determine the opinions of the coaches, there are also questions about 'whether or not a talent test is applied and, if so, talent identification tests are used' in the interview form.

Before the semi-structured interview form is distributed to the coaches, the preliminary application was carried out and the semi-structured interview form was finalized after necessary modifications were made according to the recommendations of two academicians who are experts in the field of qualitative research. In the preparation of the interview questions developed by the experts; attention was paid to ensure that the questions are clear, understandable and easy to answer and they are not complicated or guiding [23].

\subsection{Data Collection}

A semi-structured interview form, which is preferred in writing, was used to obtain the data. Prior to collecting data from the study group, sports competitions found in 2018 activity program were detected on the official website of the Turkey Wrestling Federation. Competitions, which were close to the city where the researchers lived were determined. On the dates of the competitions, the questionnaire form of "Wrestling Coaches' Methods Used in Talent Identification" prepared by the researchers was distributed to 165 coaches in different regions during the competitions (3 days). In addition, the questionnaire forms were distributed to the coaches attending the coaching course. All the forms were collected at the end of the course and the competition. The coaches were informed in advance about the content of the interview form and the written interview form was applied. The written interview form applied to the coaches was transformed into the computer and the data were recorded.

\subsection{Analysis of Data}

Data were analyzed with NVIVO. In the study, the data collected from the coaches in the field of talent identification in sports were summarized and interpreted analysis of the data. appropriate themes, the most and the least common answers are interpreted and the research findings are interpreted and evaluated [24].

\section{Results}

Table 1 presents the educational background, coaching period, coaching level and categories of the 165 coaches, 
with the average age of 37 years and the average coaching experience of eight years.

According to Table 1, the majority of the coaches hold a graduate and the average duration of coaching is 8 years. In addition, it is clear that the number of coaches who have 2nd and 3rd level coaching certificate is higher than those having the 1st, 4th and 5th level coaching certificate; and the number of coaches who work in youth setups and national teams is higher compared to the amateur and professional clubs ( Table 1).

In the present study, 42 of the athletes trained by the coaches, who applied the talent test, ranked among top 3 in the national championship, 11in international championships, 9 in European championships, 15 in World championships and 20 in Olympic championships while 9 athletes did not gain any success (Table 2).

30 of the athletes trained by the coaches, who did not apply any talent test, ranked among top 3 in national championships, 9 in international championships, 2 in European championships and 2 in World Championships while 15 athletes did not gain any success. In addition, no success was gained in the Olympic championship (Table 2). Compared to the sports performances of athletes trained by the coaches who applied the talent test and those who did not apply any talent test, it can be seen that coaches who applied talent test trained more successful athletes in terms of athletes' rankings in sports events (Table 2).

Of the 165 coaches in the present study, $106(64.24 \%)$ were detected to perform a talent test for the athletes who just started to wrestle and 59 (35.76\%) did not apply any talent test. $41(38.68 \%)$ of the coaches who applied talent tests to the wrestlers grounded their assessment on basic motoric characteristics of wrestlers, $36(33.96 \%)$ on physical structures and wrestling tendencies of the athletes, $19(17.92 \%)$ on the competition observations and technical characteristics and $10(9.43 \%)$ on intelligence.

Table 1. Education Status of Coaches, Coaching experience, Levels, and Categories

\begin{tabular}{llllllll}
\hline Education Background & N & Year & N & Levels & N & Categories & N \\
\hline Primary School & 2 & 1-4 year & 29 & 1.level & 25 & Youth setups & 65 \\
\hline Elementary School & 1 & 5-8 year & 55 & 2. level & 63 & Amateur Club & 34 \\
\hline High School & 33 & 7-12 year & 47 & 3. level & 56 & Professional Club & 26 \\
\hline Associate & 23 & 13-16 year & 15 & 4. level & 9 & National Team & 40 \\
\hline Undergraduate & 95 & 17 year and older & 19 & 5. level & 6 & & \\
\hline Graduate & 11 & & & & & & \\
\hline
\end{tabular}

Table 2. The success of Athletes Trained by the Coaches who Applied the Talent Test and Those Who did not Apply any Talent Test [N (\%)]

\begin{tabular}{lllc}
\hline \multicolumn{2}{l}{ The success of coaches who applied the talent test $(\mathrm{n} / \%)$} & \multicolumn{3}{l}{ The success of coaches who did not apply the talent test (n/\%) } \\
\hline Regional Championship & 4 & Regional Championship & 31 \\
\hline International Tournament & 11 & International Tournament & 8 \\
\hline European Championships & 9 & European Championships & 3 \\
\hline World Championships & 15 & World Championships & - \\
\hline Olympic Championship & 20 & Olympic Championship & 15 \\
\hline No Success & 9 & No Success & 59 \\
\hline Total & 106 & Total & \\
\hline
\end{tabular}

Table 3. Talent Identification Tests (n/\%)

\begin{tabular}{l|l}
\hline Did your athletes perform a talent test? & No (n/\%) \\
\hline Yes $(\mathrm{n} / \%)$ & $59(35.76 \%)$ \\
\hline $106(64,24 \%)$ & $\mathrm{n}(\%)$ \\
\hline If yes, what kind of skill test did you perform? & $41(38.68 \%)$ \\
\hline Basic Motoric Characteristics* & $36(33.96 \%)$ \\
\hline Physical structure and predisposition to wrestling & $19(17.92 \%)$ \\
\hline Competition observation and technical characteristics** & $10(9.43 \%)$ \\
\hline İnelligence & $106(100 \%)$ \\
\hline Total &
\end{tabular}

*Basic Motoric Characteristics: Endurance, Force, Speed, Flexibility and coordination, ** Competition observation and technical characteristics: Interpretation of the courage, ambition and technical capacity of the athlete during the wrestling competition. 
In this study, wrestling coaches used talent test methods to determine the basic motoric characteristics. In addition, competition observations and technical characteristics, physical structure and tendency to wrestling and intelligence have been observed in talent identification (Table 3)

According to the answers of the coaches to the question "how would you understand the talent of the new athletes in wrestling?" evaluated as independent of Table 3, the most commonly used methods are observation during wrestling competition and technical features, and physical structure and tendency to wrestling for talent identification.

Of the 165 coaches in the present study, 46 (27.88 \%) of the coaches who understand that wrestlers are talented grounded their assessment on the competition observations and technical characteristics, 41 (24.85\%) on physical structures and wrestling tendencies of the athletes, 33 $(20.00 \%)$ on basic motoric characteristics of wrestlers, 26 $(15.76 \%)$ on success and $19(11.52 \%)$ on intelligence. In addition, it can be seen that basic motoric features, achievement, and intelligence methods were also used in identifying talented athletes (Table 4).

In our study, wrestling coaches used the talent test methods to determine basic motoric characteristics. In addition, they used observation methods such as competition observation and technical characteristics, physical structure and tendency to wrestling, achievement and intelligence in the detection of the talent (Table 4).

Table 4. The Answers of the Coaches to the Question "how would you understand the Talent of the new Athletes in Wrestling?"

\begin{tabular}{ll}
\hline Talent identification methods & $\mathrm{n}(\%)$ \\
\hline $\begin{array}{l}\text { Competition observation and technical } \\
\text { characteristics }\end{array}$ & $46(27.88 \%)$ \\
\hline $\begin{array}{ll}\text { Physical structure and predisposition to wrestling } \\
\text { Basic Motoric Characteristics }\end{array}$ & $41(24.85 \%)$ \\
\hline Success & $33(20,00 \%)$ \\
\hline İntelligence & $26(15.76 \%)$ \\
\hline Total & $19(11.52 \%)$ \\
\hline
\end{tabular}

\section{Discussion}

Of the 165 coaches in the present study, 106 (64.24\%) were detected to perform a talent test for the athletes who just started to wrestle and 59 (35.76 \%) do not apply. 41 $(38.68 \%)$ of the coaches who applied talent tests to the wrestlers grounded their assessment on basic motoric characteristics of wrestlers, $36(33.96 \%)$ on physical structures and wrestling tendencies of the athletes, 19 $(17.92 \%)$ on the competition observations and technical characteristics and $10(9.43 \%)$ on intelligence.

In this study, wrestling coaches used talent test methods to determine basic motoric characteristics.

In sports, many components such as genetic background, body composition [25-28], anaerobic capacity [29], anatomical structure, maturation of sport-specific abilities, age, height [60], weight [30], and strength [65] and gender affect sporting performance and provide important clues about the sports branch to which the individual has a tendency [31].

For this reason, talent identification plays an important role in determining the promising athlete candidates and directing them to the sports branch to which they have a tendency [32-34].

Talent tests have been used to identify the talent of the athletes in many sports branches. Various tests have been used to identify talented athletes; such as motor performance tests of speed performance and football special technical skills (sprint, agility, dribbling, ball control, shooting) for young German football players [35], body composition, standing long jump, static and dynamic balance, coordination, quickness and speed tests elite women judo athletes [36], throwing the ball to the hoop, throwing the ball to the hoop by skimming, dribbling, bringing the pins down, throwing the ball to the target on the wall and fast pass on the wall for basketball players [36], wrestling competitions, $800 \mathrm{~m}$ running test, $30 \mathrm{~m}$ running test, flexibility, mental skill tests for wrestlers [37]. Finger and hand grip strength, standing long jump test, health ball throw test, flexibility test (sit-reach), active leap test, anaerobic power test, $20 \mathrm{~m}$ sprint run, pro-agility quickness test and $20 \mathrm{~m}$ shuttle run tests were performed for children in the age group of 9-14 [38].

As presented in the literature review, talented athletes have been determined through various talent tests. In the findings of the present study, the talent test methods of the wrestling coaches used on the athletes were more comprehensive than the studies in the literature.

In the present study, 42 of the athletes trained by the coaches, who applied talent test, ranked among top 3 in the national championship, 11 in international championships, 9 in European championships, 15 in world championships and 20 in Olympic championships while 9 athletes did not gain any success (Table 2). 30 of the athletes trained by the coaches, who did not apply any talent test, ranked among top 3 in national championships, 9 in international championships, 2 in European championships and 2 in World Championships while 15 athletes did not gain any success. In addition, no success was gained in the Olympic championship (Table 2). Compared to the sports performances of athletes trained by the coaches who applied the talent test and those who did not apply any talent test, it can be seen that coaches who applied talent test trained more successful athletes in terms of athletes' rankings in sports events.

Many factors influence achievement in sports. It has been reported that age, anthropometric and fitness characteristics of young rugby league players [39], body composition of weight sports [40], somatotypes characteristics of young and professional male basketball players [41], technical characteristics of young footballers 
[28] have an impact on achievement. The genetic background in sports has been reported to affect physiological characteristics such as strength, endurance, type of muscle fibers, cardiopulmonary and lung capacity $[21,43]$. It is suggested that individuals with ACE genotypes can be more successful in sports requiring speed-force such as sprinting, long jump, high jump, disc throwing, or short distance swimming. However, genetic factors also have positive effects on sportive performance $[44,45]$.

Literature studies report that many components such as physical and physiological characteristics, anatomical structure and body fat content are effective in the success of the individuals in sports. In the present study, the physical structure and tendency of the individual to sports along with these components, the observation of the competition and the technical characteristics of the athletes, the intelligence of the individual to grasp a movement and the ability to make the right move within the competition affect the sportive achievement.

Of the 165 coaches in the present study, 46 (27.88\%) of the coaches who understand that wrestlers are talented grounded their assessment on the competition observations and technical characteristics, $41(24,85 \%)$ on physical structures and wrestling tendencies of the athletes, 33 $(20.00 \%)$ on basic motoric characteristics of wrestlers, 26 $(15.76 \%)$ on success and $19(11.52 \%)$ on intelligence.

In addition, competition observations and technical characteristics, physical structure and tendency to wrestling and intelligence have been observed in talent identification. In parallel with the present study, the decisions of coaches and experts in identifying talented athletes often play a decisive role in talent screening and selection processes $[46,47]$.

\section{Suggestions}

In the wrestling sport, the talent test methods used to identify the talent by the coaches (basic motor characteristics, competition observation, and technical characteristics, physical structure and tendency to wrestling and intelligence) can be shown as a criterion in the identification of talented athletes.

The wrestling coaches in the present study used talent test methods, but not all the basic motor characteristics. Some coaches, for example, evaluated the strength and endurance of athletes, while others took into consideration flexibility, speed, and coordination. It is thought that coaches can obtain more successful results if they evaluate the basic motoric features as a whole. Besides, although the coaches evaluated the athletes' intelligence characteristics, it was found that they did not apply any intelligence test to the athletes. Therefore, it is recommended to use intelligence tests in the literature instead of testing the intelligence of the athlete through observation while the skill test methods are applied to athletes.
In recent years, genetic tests have been used to identify talented athletes. Although many studies suggest that genetic tests should be used in talent selection, it is not mentioned that genetic tests should be a criterion in talent identification in literature. However, there should be a criterion in talent selection.

In general, the physical characteristics, physical and physiological capacities, anatomical structures, basic motoric characteristics, intelligence, body composition and somatotype characteristics of the individuals who are new to sports should be tested in the light of scientific characteristics while performing talent test methods.

\section{REFERENCES}

[1] Çankaya C, Arabacı R, Doğan M, Kılıç C. (2004). Bursa'daki güreş eğitim merkezi ve faal güreş kulüplerinde yetenek seçimi. Beden Eğitimi ve Spor Bilimleri Dergisi, 6(1), 11-17.

[2] Kaynar, Ö. Bilici M.F. (2018). Investigation of Talent Selection Methods in Different Sports Branches. Journal of Education and Training Studies, 6(n12a), 44-48.

[3] Kaynar, Ö. ve Bilici, M.F. (2017). Analysis of the Talent Selection in Turkish Wrestling. International Journal of Science Culture and Sport, 5(4):347-355.

[4] Vaeyens R, Güllich A, Warr CR, et al.(2009). Talent identification and promotion programmes of Olympic athletes. J Sports Sci.27(13):1367-80.

[5] Meylan C, Cronin J, Oliver J et al. (2010). Talent identification in soccer: the role of matu-rity status on physical, physiological and technical characteristics. Int J Sport SciCoach,5,571-592.5.

[6] Dodd, K. D., \& Newans, T. J. (2018). Talent identification for soccer: Physiological aspects. Journal of science and medicine in sport, 21(10), 1073-1078.

[7] Hettinga FJ, de Koning JJ, Schmidt LJI, Wind AC, MacIntosh B, Foster C. (2011). Optimal pacing 292 strategy: From theoretical modelling to reality in $1500-\mathrm{m}$ speed skating. Br. J. Sports Med. 293 45(1):30-35.

[8] Durand-Bush N, Salmela JH. (2001). The development of talent in sport. In: Singer RN, Hausenblas HA, Janelle CM, editors. Handbook of sport psychology 2nd ed. New York: Wiley, 269-89

[9] Elferink-Gemser, M. T., \& Hettinga, F. J. (2017). Pacing and Self-regulation: important skills for talent development in endurance sports. International journal of sports physiology and performance, 12(6), 831-835.

[10] Deprez, D., Fransen, J., Boone, J., Lenoir, M., Philippaerts, R., \& Vaeyens, R. (2015). Characteristics of high-level youth soccer players: Variation by playing position. Journal of Sports Sciences, 33(3), 243-254.

[11] Vaeyens, R., Lenoir, M., Williams, A. M., \& Philippaerts, R. M. (2008). Talent identification and development programmes in sport. Sports Medicine, 38(9), 703-714 
[12] Bompa, T.O. (2003). Antrenman kuramı ve yöntemi. (T. (çev) Bağırgan, Ed.). Ankara: Bağırgan Yayınevi.

[13] Kaynar, Ö, Seyhan S, ve Bilici M.F. (2018).Güreşçilerde Sportif Başarıyı Olumsuz Etkileyen Faktörlerin İncelenmesi. Beden Eğitimi ve Spor Bilimleri Dergisi, 20(1), 54-59.

[14] Mirwald ,R.L, Baxter-Jones A. D. G, Bailey, D.A, Beunen G. P (2002). An assessment of maturity from anthropometric measurements. Medicine and Science in Sports and Exercise, 34(4), 689-694.

[15] Barley, D.A. (1997). The Saskatchewan pediatric bone mineral accrual study: bone mineral acquisition during the growing years. Int. J. Sports Med., 18, 191-194.

[16] Arabac1, R. Koparan S., Öztürk F., Mutlu M. (2008).Olimpiyatlar İçin Sporda Yetenek Seçimi ve Spora Yönlendirme Projesi II. Aşama Sonuçlarının İncelenmesi (Bursa Örneği). Sport Sciences, 3(2), 86-98.

[17] Hulse, M.A., Morris, J.G., Hawkins, R.D., Hodson, A., Nevill, A.M., \& Nevill, M. E. (2013). A field-test battery for elite, young soccer players. International journal of sports medicine, 34(04), 302-311.

[18] Eynon, N. Ruiz, J.R., Oliveira, J., Duarte, J.A., Birk, R. Lucia., A. (2011). Genes and elite athletes: A road map for future research. J Physiol, 598, 3063-3070.

[19] Milanese, C., Bortolam1, O., Bertucco, M., Verlato, G., Zancarano, C. (2010). Anthropometry and Motor Fitness in Children Aged 6-12 Years. Journal of Human Sport \& Exercise, 5 (2), 265-279.

[20] Yang, N., MacArthur, D.G., Gulbin, J.P., Hahn, A. G., Beggs, A. H., et al. (2003). ACTN3 genotype is associated with human elite athletic performance. The American Journal of Human Genetics, 73(3), 627-631.

[21] Mustafina, L.J., Naumov, V.A., Cieszczyk, P., Popov, D.V., Lyubaeva, E.V., et al. (2014). AGTR2 gene polymorphism is associated with muscle fibre composition, athletic status and aerobic performance. Exp. Physiol, 99, 1042-1052.

[22] Türk Güreşi 1609 Madalya İle Zirvede, http://www.tgf.gov.tr/tr/index.php/main/turk-guresi-1512madalya-ile-zirvede/ 17.12.2018.

[23] Yılmaz, K., Altınkurt, Y. ve Çokluk, Ö. (2011). "Eğitim İnançları Ölçeğinin Geliştirilmesi: Geçerlik ve Güvenirlik Çalışması", Kuram ve Uygulamada Eğitim Bilimleri, S: 11 (1), 335-350.

[24] Büyüköztürk Ş, Çakmak EK, Akgün ÖE, Karadeniz Ş, Demirel F. (2011). Bilimsel Araştırma Yöntemleri. (9. Bask1). Ankara: Pegem Akademi Yayıncılık.

[25] Baxter-Jones A.D, Helms P.J. (1996). Effects of training at young age: a review of the training of young athletes (TOYA) study. Pediatr Exerc Sci, 8, 310-27.

[26] Roemmich J.N, Rogol A.D. (1995). Physiology of growth and development. Its relationship to performance in the young athlete. Clin Sports Med, 14(3):483-502.

[27] Beunen GP, Malina RM, Lefevre J, et al.(1997).Prediction of adult stature and noninvasive assessment of biological maturation. Med Sci Sports Exerc, 29(2):225-30.

[28] Herman-Giddens M.E, Wang L, Koch G.(2001).Secondary sexual characteristics in boys: estimates from the National Health and Nutrition Examination Survey III. Arch Pediatr Adolesc Med 155(9):1022-8.

[29] Inbar O, Bar-Or O. (1986). Anaerobic characteristics in male children and adolescents. Med Sci Sports Exerc,18(3):264 9.

[30] Gil, S.M., Zabala-Lili, J., Bidaurrazaga-Letona, I., Aduna, B., Lekue, J. A., et al.(2014). Talent identification and selection process of outfield players and goalkeepers in a professional soccer club. Journal of Sports Sciences, 32(20), 1931-1939.

[31] Epstein, D. (2013). The Sports Gene. Inside the Science of extraordinary Athlethic Performance. The gene-Free Model of Expertise, Penguin Group New York.

[32] Wattie, N., \& Baker, J. (2017). Why conceptualizations of talent matter: implications for skill acquisition and TID. The Routledge handbook of talent identification and development in sport. London: Routledge.

[33] Ayan, V., Mülazımoğlu, O. (2010). Sporda yetenek seçimi ve spora yönlendirmede $8-10$ yaş grubu kız çocuklarının fiziksel özelliklerinin ve bazı performans profillerinin incelenmesi (Ankara örneği). Niğde Üniversitesi Beden Eğitimi ve Spor Bilimleri Dergisi, 4(3), 152-159.

[34] Unnithan, V., White, J., Georgiou, A., Iga, J., \& Drust, B. (2012). Talent identification in youth soccer. Journal of Sports Sciences, 30, 1719-1726.

[35] Höner, O.,Votteler, A.,Schmıd, M., Schultz, F. \&Roth, K. (2015). Psychometric properties of the motor diagnostics in the German football talent identification and development programme. Journal of Sports Sciences, 33; (2), 145-159.

[36] Demiral, Ş., Erdemir, İ., Kızılyaprak, A.H. (2011). Bayan judocularda yetenek seçimi. USAD, 3(1), 29-31.

[37] Özal, M, Gökdemir, K, Arslan, C, Orhan, S. (2003). Güreş Eğitim Merkezlerine Yetenekli Sporcu Seçme Sınavlarında Uygulanan Testlere İlişskin Bir Araștırma. Gazi Beden Eğitimi ve Spor Bilimleri Dergisi (Gazi BESBD), 7 (2), 19 32.

[38] Bayraktar, I., Yaman, N., Zorba, E., Yaman, M., \& Günay, M. (2016). The Analysis of Certain Differences in Motor Skills of Sedentary Male Children in the 9-14 Age Group Based on the Biological Maturity. Universal Journal of Educational Research, 4(8), 1894-1902.

[39] Till, K., Cobley, S., O’Hara, J., Morley, D., \& Chapman, C. (2015). Retrospective analysis of anthropometric and fitness characteristics associated with long-term career progression in Rugby League. Journal of Science and Medicine in Sport, $18,310-314$.

[40] Kürkçü, R., Hazar, F., Özdağ, S. (2009). Futbolcuların Vücut Kompozisyonu ,Vücut Bileşenleri ve Somatotip Özellikleri Üzerine Bir İnceleme. Niğde Üniversitesi Beden Eğitimi ve Spor Bilimleri Dergisi, 3 (2), 113-119.

[41] Gryko, K., Kopiczko, A., Mikołajec, K., Stasny, P., \& Musalek, M. (2018). Anthropometric variables and somatotype of young and professional male basketball players. Sports, 6(1), 9

[42] Matta, M.D.O., Figueiredo, A.J.B., Garcia, E.S., Werneck, F.Z., Seabra, A. (2014).Morphological and maturational 
predictors of technical performance in young soccer players. Motriz, 20(3), 280-285.

[43] Sözen, A.B. (1996).Turkiye Birinci Profesyonel Futbol Ligi Futbolcularında Elektrokardiyografi ve Ekokardiografi Bulguları, (TU), İstanbul Üniversitesi, İstanbul Tip Fakültesi, İç Hastalıkları Anabilim Dalı, İstanbul.

[44] Tucker, R., \& Collins, M. (2012). What makes champions? A review of the relative contribution of genes and training to sporting success. British Journal of Sports Medicine, 6, 555561.

[45] Alonso, L., Souza, E., Oliveira, M., Nascimento, L., Dantas, P. (2014). Heritability of aerobic power of individuals in northeast Brazil, Biol. Sport, 31,267-270.

[46] Sarmento, H., Anguera, M.T., Pereira, A., \& Araújo, D. (2018). Talent identification and development in male football: A systematic review. Sports Medicine, 48(4), 907-931.

[47] Williams, A.M., \& Ericsson, K.A. (2005). Some considerations when applying the expert performance approach in sport. Human Movement Science, 24, 283-307. 